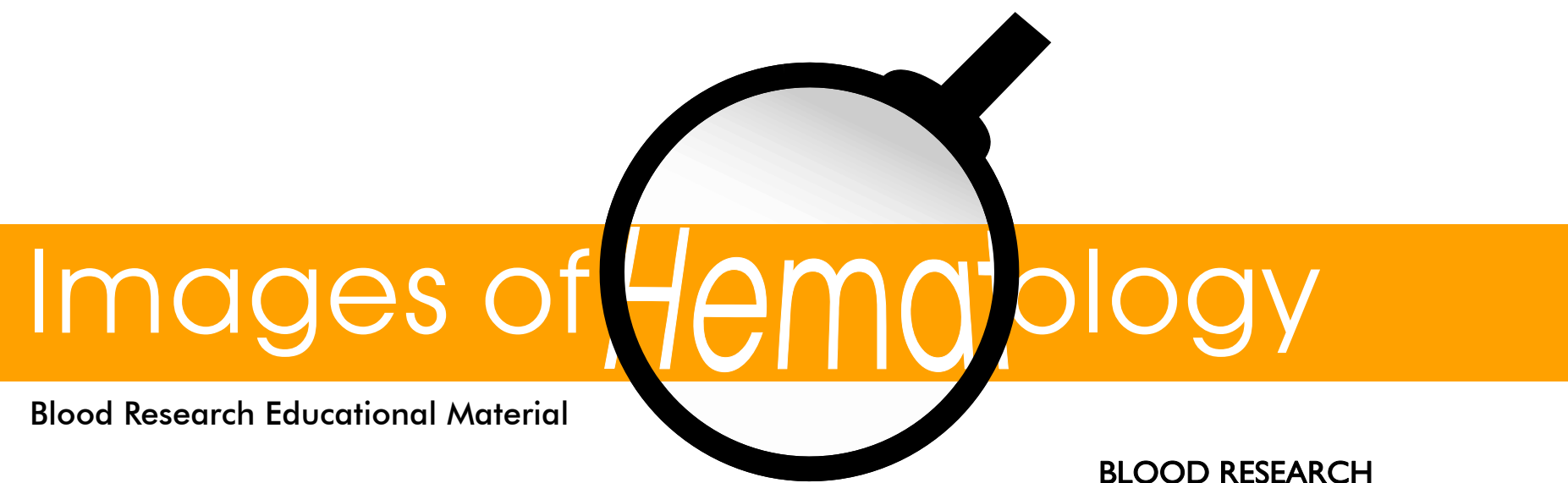

Volume $49 \cdot$ Number $3 \cdot$ September 2014

http://dx.doi.org/10.5045/br.2014.49.3.147

\title{
Reed-Sternberg-like cells in follicular lymphoma
}

Eun-mi Son, Jooryung Huh

Department of Pathology, Asan Medical Center, University of Ulsan College of Medicine, Seoul, Korea

Correspondence to Jooryung Huh, M.D., Ph.D., Department of Pathology, Asan Medical Center, University of Ulsan College of Medicine, 88, Olympic-ro 43-gil, Songpa-gu, Seoul 138-736, Korea, E-mail: jrhuh@amc.seoul.kr

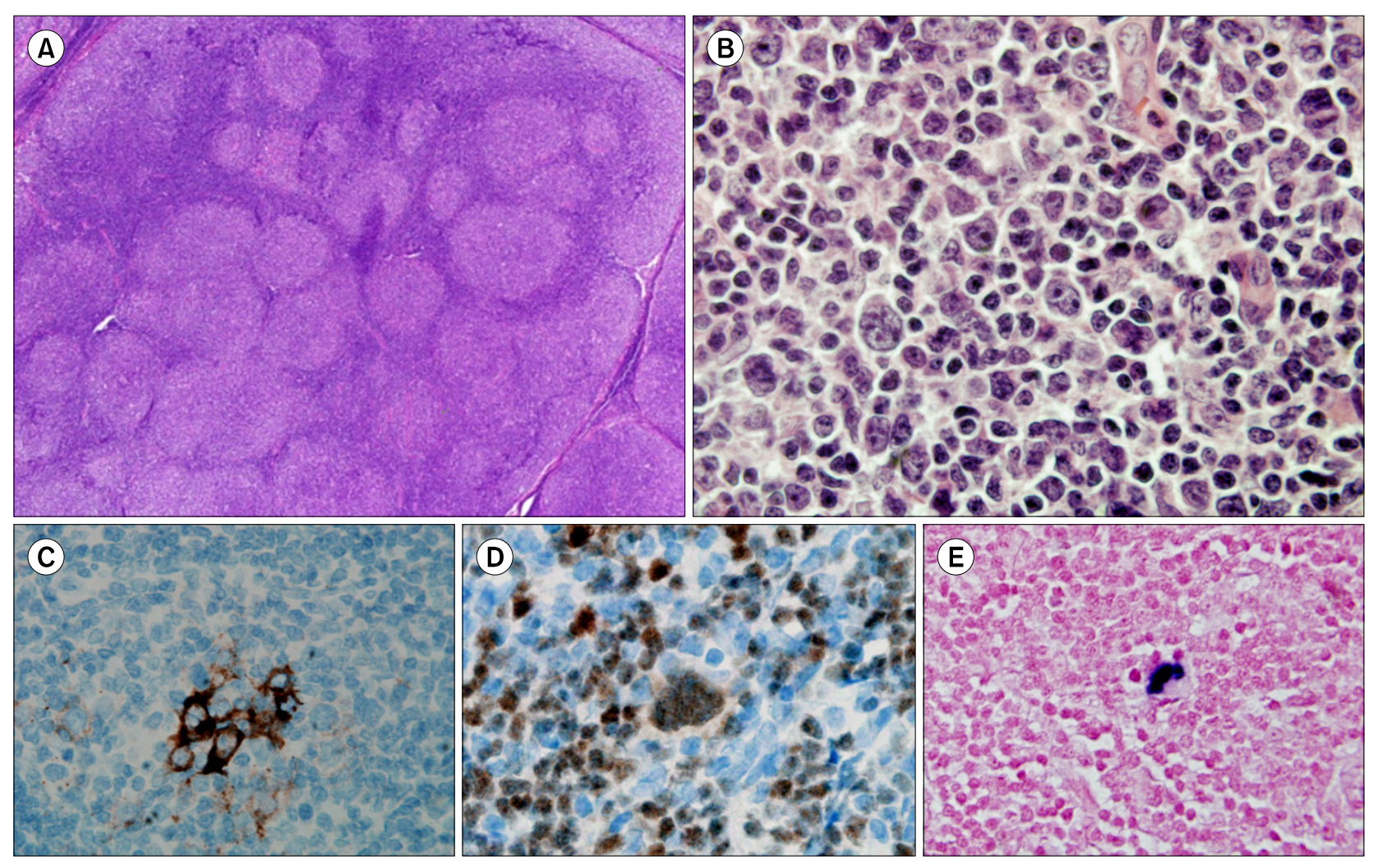

A 32-year-old woman presented with abdominal bloating and postprandial discomfort for 3 weeks. Multiple neck and axillary lymph nodes were palpable on physical examination. The lymph nodes were involved by low grade follicular lymphoma with effacement by closely packed neoplastic follicles without mantle zones (A). Tumor cells were predominantly centrocytes with a mixture of a few centroblasts. However, a few follicles also showed isolated large binucleated or mononucleated cells with prominent nucleoli, perinuclear halo, and abundant cytoplasm resembling Reed-Sternberg cells (RS-like cells) (B), without the appropriate background of Hodgkin lymphoma. The RS-like cells were positive for CD30, PAX5, and Epstein-Barr virus RNA (EBER) (C-E). The RS-like cells arising in follicular lymphoma in the present case may be the precursors of Hodgkin lymphoma, indicative of histologic transformation. 